University of Nebraska - Lincoln

DigitalCommons@University of Nebraska - Lincoln

Papers in the Earth and Atmospheric Sciences

Earth and Atmospheric Sciences, Department

\title{
The influence of temperature, moisture, and eolian activity on Holocene lake development in West Greenland
}

\author{
Bianca B. Perren \\ Université de Franche-Comté, bianca.perren@univ-fcomte.fr
}

N. J. Anderson

Loughborough University, Loughborough, UK, N.J.Anderson@lboro.ac.uk

Marianne S. V. Douglas

University of Alberta, marianne.douglas@ualberta.ca

Sherilyn C. Fritz

University of Nebraska-Lincoln, sfritz2@unl.edu

Follow this and additional works at: https://digitalcommons.unl.edu/geosciencefacpub

Perren, Bianca B.; Anderson, N. J.; Douglas, Marianne S. V.; and Fritz, Sherilyn C., "The influence of temperature, moisture, and eolian activity on Holocene lake development in West Greenland" (2012). Papers in the Earth and Atmospheric Sciences. 391.

https://digitalcommons.unl.edu/geosciencefacpub/391

This Article is brought to you for free and open access by the Earth and Atmospheric Sciences, Department of at DigitalCommons@University of Nebraska - Lincoln. It has been accepted for inclusion in Papers in the Earth and Atmospheric Sciences by an authorized administrator of DigitalCommons@University of Nebraska - Lincoln. 


\title{
The influence of temperature, moisture, and eolian activity on Holocene lake development in West Greenland
}

\author{
Bianca B. Perren, ${ }^{1}$ N. John Anderson, ${ }^{2}$ Marianne S. V. Douglas, ${ }^{3}$ and Sherilyn C. Fritz ${ }^{4}$ \\ 1. UMR CNRS 6249 Chrono-Environnement, Université de Franche-Comté, 25030 Besançon, France; \\ Corresponding author - email bianca.perren@univ-fcomte.fr \\ 2. Department of Geography, Loughborough University, Loughborough LE11 3TU, UK \\ 3. Department of Earth and Atmospheric Sciences, University of Alberta, Edmonton, AB T6G 2E1, Canada \\ 4. Department of Earth and Atmospheric Sciences, University of Nebraska-Lincoln, Lincoln, NE 68588-0340, USA
}

\begin{abstract}
Holocene paleolimnological records (diatoms, organic content, spectrally inferred sediment chlorophyll-a) from three West Greenland lakes $\left(\sim 67^{\circ} \mathrm{N}\right)$ situated along a transect from the outer coast to a nunatak at the periphery of the Greenland Ice Sheet are used to explore the nature of regional postglacial lake development and its relationship to Holocene climate evolution. The lakes were deglaciated asynchronously by approximately 4 ka (earliest on the coast) and thus their sediment records document different starting points of Holocene ontogeny, both temporally and paleoclimatically. Despite similar time-transgressive characteristics of the diatom stratigraphies, overarching climatic factors, principally effective moisture, and eolian inputs, govern individual lake development. The transition to Neoglaciation between 5.6 and $4 \mathrm{ka} \mathrm{BP}$ marks a shift toward a cooler, moister, windier climate from the aridity and higher temperatures of the mid-Holocene (8-6 ka BP). A shift toward increased aridity, windiness, and eolian activity is documented in the interior lakes over the last 500 years. These lake records demonstrate the sensitivity of freshwater lakes in
\end{abstract}

arid regions to changes in effective moisture and highlight the role of wind and eolian activity in Arctic lake environments.

Keywords: Arctic, Holocene, diatoms, lake ontogeny, West Greenland

\section{Introduction}

The impacts of recent climate change have been documented across the circumpolar North (ACIA 2004), and the increase in Arctic surface air temperature exceeds the global average threefold over the last century (Trenberth et al. 2007). Accelerating mass loss from circumpolar mountain glaciers and ice caps (Gardner et al. 2011), reduced sea ice (Serreze et al. 2009), and unprecedented change in aquatic ecosystems (Smol et al. 2005) all point to a rapidly warming Arctic environment. These changes are consistent with model predictions of the amplification of polar warming (Holland and

This paper is one of 18 published in a special issue (48:1) of Journal of Paleolimnology, edited by Darrell Kaufman and dedicated to reconstructing Holocene climate and environmental change from Arctic lake sediments. 
Bitz 2003) and are expected to accelerate in the future with increased greenhouse gas emissions.

Recent change is especially a concern in Greenland, where record high summer temperatures in the last decade have accelerated rates of discharge and melting from the Greenland Ice Sheet, with possible consequences for global sea level as well as ocean circulation (Rignot et al. 2011). Despite the wealth of paleoclimatic data available from the Greenland Ice sheet cores (NGRIP, GISP), paleoclimatic archives from the Greenland coastal margin are scarce, underscoring their importance for placing recent change in the land-based areas surrounding the ice sheet in a longer timescale perspective.

\section{Lake ontogeny}

The natural pattern of lake development, or ontogeny, is important for understanding background variability of aquatic ecosystems and for estimating the relative effects of human stressors (e.g. climate change, acidification, eutrophication; Pennington 1943, 1978; Deevey 1942; Renberg 1990a). The earliest paleoecological studies of lake ontogeny described lakes that infill and become increasingly nutrient-rich with age (eutrophication; Deevey 1942). Paleolimnological reconstructions from lakes in glaciated northern temperate latitudes (e.g. Alaska, Labrador, Sweden) indicate that lakes in these regions typically become more acidic (Renberg 1990a; Bigler et al. 2002) and oligotrophic (Engstrom and Hansen 1985; Engstrom et al. 2000) with time. Receding glaciers leave behind catchments rich in base cations that efficiently buffer catchment and atmospheric acidity during the decades following lake formation. However, as the landscape stabilizes, organic-rich soils develop, and forests grow, and, as result, this edaphic source of alkalinity and nutrients is diminished, creating a lake with lower $\mathrm{pH}$, fewer nutrients, and higher dissolved organic carbon (DOC) over time (Whitehead et al. 1989; Engstrom et al. 2000).

Whether this model is true for younger, treeless Arctic landscapes is largely untested. On Baffin Island, Holocene lake ontogeny is tightly coupled to declining temperatures and $\mathrm{pH}$ (Michelutti et al. 2007). Lakes show maximum diatom-inferred $\mathrm{pH}$ at the beginning of the Holocene, coincident with highest summer temperatures. As temperatures decline through the Holocene, prolonged ice cover regulates internal DIC dynamics, leading to lowered $\mathrm{pH}$, and the development of acidophilic diatom taxa. Indeed, a progression of declining $\mathrm{pH}$ and temperatures is evident over successive interglacials, reinforcing this basic acidification pattern (Wilson et al. 2012).

Based on aquatic macrofossil evidence, Fredskild (1983) hypothesized that lakes in West Greenland underwent rapid oligotrophication with the stabilization of soils and amelioration of climate following deglaciation (starting ca. $8 \mathrm{ka} \mathrm{BP}$ ). Since Fredskild's early studies, the region between Sisimiut and Kangerlussuaq in West Greenland $\left(\sim 67^{\circ} \mathrm{N}\right)$ has been the focus of ongoing paleolimnological and paleoclimatic studies. Closed-basin lakes at the head of the Kangerlussuaq fjord document large fluctuations in temperature and effective moisture during the early and late Holocene (McGowan et al. 2003; Anderson and Leng 2004; Aebly and Fritz 2009; D'Andrea et al. 2011). Holocene stratigraphies from several sub-saline lakes document the long-term history of these lakes with respect to catchment development and Holocene climate (Anderson et al. 2008; McGowan et al. 2008; Heggen et al. 2010). Modern species-environment relationships have also been documented for diatoms (Ryves et al. 2002; Perren 2007), chrysophytes (Pla and Anderson 2005), and chironomids (Brodersen and Anderson 2002). However, despite the wealth of paleoecological data from this region, few studies have focused on the oligotrophic freshwater lakes (freshwater is defined here as having a modern conductivity $<300 \mu \mathrm{S} \mathrm{cm}^{-1}$ ) that are typical of the $>20,000$ lakes in the region and the rest of the Greenland coast.

Here we present diatom-based regional postglacial records from three freshwater lakes in an effort to refine our understanding of freshwater lake ontogeny in West Greenland and the way in which these lakes record Holocene climate variability in terms of changing temperature, effective moisture, and eolian activity.

\section{Methods}

Study area

The 180-km-long ice-free margin of West Greenland $\left(\sim 67^{\circ} \mathrm{N}\right)$ contains tens of thousands of lakes (Figure 
1). The region is underlain by Precambrian supracrustal rocks of the Nagssugtoqidian Mobile Belt, a unit that is composed mainly of gneisses intruded by younger amphibolitic and doleritic dykes (Escher et al. 1976). The Greenland Ice Sheet began retreating from the coast approximately $11.5 \mathrm{ka} \mathrm{BP}$, reaching behind its present margin by approximately $6 \mathrm{ka}$ BP (Kelly 1985; van Tatenhove et al. 1996). After $\sim 4$ ka BP, local glaciers advanced towards their Little Ice Age maxima near the present ice margin (Kelly 1985). The resulting landscape is one of moderate relief, with undulating bedrock hills, a local topography of 300-600 m asl, patchy thin till veneers, and an extensive ice-proximal sandar.

Of particular importance to this study is the strong climate gradient across the region. Near the coast, climate is maritime, with an average annual precipitation of $383 \mathrm{~mm}$, and muted seasonal temperature variation. Maritime air is blocked by the Sukkertoppen glacier in the southwest, and the ice sheet to the east, resulting in a continental and arid climate in the interior. The town of Kangerlussuaq, at the head of the fjord, has a lower average precipitation (149 $\mathrm{mm} \mathrm{a}^{-1}$ ) and greater seasonality than the coast (Cappelen et al. 2001).

The three study lakes span a broad longitudinal transect of West Greenland from the edge of the ice sheet to the coast. They were chosen to isolate the effects of the different climatic regimes and contrasting landscape ages in the region. The coastal site (SS49) was deglaciated c. $10 \mathrm{ka}$ BP. The climate is maritime, with cool-moist summers, persistent fog and relatively shorter ice-free periods. The vegetation cover is continuous and dominated by peat and Empetrum nigrum heaths. The lake is polymictic, 20.7 ha, dilute (conductivity $=27 \mu \mathrm{S} \mathrm{cm}{ }^{-1}$ ), slightly acidic $(\mathrm{pH}=6.6)$, with a maximum depth of $10.5 \mathrm{~m}$ (Table 1$)$.

Nearer the ice margin (SS16), the landscape was deglaciated approximately $8.5 \mathrm{ka} \mathrm{BP}$. The climate is continental, with little precipitation and high rates of evaporation (E > P; Leng and Anderson 2003). South-facing slopes are commonly devoid of vegetation, but elsewhere a shrub tundra consisting of Betula nana, Ledum palustre, and Salix spp. is established. The lake is small ( $3 \mathrm{ha}$ ), dimictic, circumneutral ( $\mathrm{pH}$ $=7.2$ ), and dilute (conductivity $=106.8 \mu \mathrm{S} \mathrm{cm}^{-1}$ ), with a maximum depth of $12 \mathrm{~m}$ (Table 1). The lake has no discernible inflow and a small outflow.
Table 1. Average physical and chemical characteristics of the three study lakes (1996-2000).

\begin{tabular}{lrrr}
\hline & SS49 & SS16 & SS32 \\
\hline Latitude $\left({ }^{\circ} \mathrm{N}\right)$ & 66.86 & 66.91 & 66.97 \\
Longitude $\left({ }^{\circ} \mathrm{W}\right)$ & 52.64 & 50.46 & 49.80 \\
Elevation (m asl) & 330 & 477 & 470 \\
Maximum depth (m) & 10.5 & 12.2 & 21 \\
Lake area (ha) & 20.7 & 3.3 & 16.3 \\
pH & 6.6 & 7.2 & 7.3 \\
$\mathrm{Conductivity}\left(\mu \mathrm{cm}^{-1}\right)$ & 26.7 & 106.8 & 51.0 \\
$\mathrm{TN}\left(\mu \mathrm{L} \mathrm{L}^{-1}\right)$ & 143.0 & 450.0 & 307.5 \\
$\mathrm{TP}\left(\mu \mathrm{g} \mathrm{L}^{-1}\right)$ & 3.7 & 11.7 & 5.0 \\
$\mathrm{~N}^{\mathrm{P} \text { molar ratio }}$ & 85.5 & 85.1 & 136.0 \\
$\mathrm{Ca}^{2+}\left(\mathrm{mg} \mathrm{L}^{-1}\right)$ & 123.0 & 242.5 & 208.9 \\
$\mathrm{Mg}^{2+}\left(\mathrm{mg} \mathrm{L}^{-1}\right)$ & 48.0 & 276.2 & 228.5 \\
$\mathrm{Na}^{+}\left(\mathrm{mg} \mathrm{L}^{-1}\right)$ & 100.3 & 93.1 & 81.4 \\
$\mathrm{~K}^{+}\left(\mathrm{mg} \mathrm{L}^{-1}\right)$ & 8.7 & 36.1 & 33.6 \\
$\mathrm{Alkalinity}\left(\mathrm{mg} \mathrm{L}^{-1}\right)$ & 86.7 & 465.7 & 365.3 \\
$\mathrm{SO}_{4}{ }^{2-}\left(\mathrm{mg} \mathrm{L}^{-1}\right)$ & 30.7 & 7.3 & 24.0 \\
$\mathrm{Cl}^{-}\left(\mathrm{mg} \mathrm{L}^{-1}\right)$ & 102.0 & 61.1 & 56.6 \\
\hline
\end{tabular}

The third site, SS32 or "Nunatak Lake," lies on a nunatak within the Greenland Ice Sheet approximately $5 \mathrm{~km}$ from its margin. It was deglaciated approximately $5.6 \mathrm{ka} \mathrm{BP}$, although moraine evidence from the nearby ice margin suggests several subsequent readvances during the late Holocene (Kelly 1985; van Tatenhove et al. 1996). The lake is also circumneutral $(\mathrm{pH}=7.3)$ and dilute $\left(51 \mu \mathrm{S} \mathrm{cm}^{-1}\right)$, medium sized (16 ha), and the deepest $\left(Z_{\max }=21 \mathrm{~m}\right)$ of the study lakes (Table 1). SS32 is wind stressed and isothermal during summer months $\left(\sim 8{ }^{\circ} \mathrm{C}\right.$, July 1999). It has scant catchment vegetation and poorly developed soils.

\section{Coring}

All three lakes were cored between 1997 and 1999 from the lake-ice surface using a modified $10 \mathrm{~cm}$ diameter Russian corer. The sediment-water interface was retrieved separately using either a Kajak gravity corer (SS16 and SS32) or a freeze corer (SS49). Kajak cores were sampled at $0.5-1 \mathrm{~cm}$ intervals in the field. The Russian and freeze cores were documented and sectioned in the laboratory. Because each lake was initially cored and analyzed for different projects and extra sediment was not always available for analysis, there are differences in the proxies analyzed for each core detailed below. 
Dating

Radiocarbon dating was carried out using a variety of materials: bulk sediments, terrestrial macrofossils, humic acids, and base-insoluble humin (Table 2). All radiocarbon ages were calibrated to calendar years before 1950 (BP) using Calib 5.0.1 software (Stuiver and Reimer 1993). SS32 and SS16 surface cores were dated using ${ }^{210} \mathrm{~Pb}$ radiometry and a constant rate of supply age model (CRS; Appleby and Oldfield 1978). Radiocarbon and ${ }^{210} \mathrm{~Pb}$ dates were combined to produce an age-depth model for each lake sequence using a modification of the CLAM function (Blaauw 2010) in R.

\section{Organic carbon and magnetic susceptibility}

Organic-matter $(\mathrm{OM})$ content was estimated for SS32 and SS16 using loss-on-ignition, where the sediment samples were dried and combusted in a muffle furnace at $550{ }^{\circ} \mathrm{C}$ for $5 \mathrm{~h}$ (Heiri et al. 2001). Total organic content (TOC) for SS49 was measured on a Carlo-Erba elemental analyzer following acidification of samples to remove any carbonates. Magnetic susceptibility was measured on SS16 cores by a Bartington MS2E surface scanning sensor.

\section{Diatoms}

Diatoms were isolated from freeze-dried sediments using $30 \% \mathrm{H}_{2} \mathrm{O}_{2}$ digestion, following standard methods for large sample numbers (Renberg 1990b). Diatom concentration was estimated using a known quantity of divinylbenzene (DVB) microspheres added to the samples (Battarbee and Kneen 1982). Sample aliquots were allowed to dry on plain glass coverslips and permanently mounted using Naphrax ${ }^{\mathrm{TM}}$ mounting medium. Diatom valves were identified and enumerated using phase contrast light microscopy at $1,000 \times$ under oil immersion. Identifications were confirmed with scanning electron microscopy using a JEOL-6301F field-emission SEM operated at $25 \mathrm{kV}$ following sputtering of dried diatom slurries with $\mathrm{Au}$. For each sample, at least 400 diatoms were identified from each slide, with the exception of SS49 where reduced count sizes (c. 250-300 valves) were used (cf. Renberg 1990a) to efficiently analyze a large number of samples. Diatom taxonomy followed reference literature of Krammer and Lange-Bertalot (1986, 1988, 1991a, 1991b), and the Greenland diatom floras of Foged (1953, 1955, 1972, 1977).

Diatom zones for each of the cores were created by stratigraphically constrained cluster analysis using a minimum variance algorithm applied to a matrix of squared Euclidean distances (Grimm 1987). Chronosequences of the downcore diatom data were created by plotting the downcore diatom data as passive samples on the 40-lake West Greenland canonical correspondence analysis (CCA; Perren 2007). In order to compare the synchronous aspects of the data, sample scores from axis 1 were plotted against time.

\section{Chlorophyll- $a$ content}

Estimates of sedimentary chlorophyll- $a$ content were obtained following procedures and the calibration algorithm outlined in Wolfe et al. (2006). Sediments were freeze-dried and sieved through a $45 \mathrm{~lm}$ mesh. These samples were then illuminated, and their spectral reflectance was measured using a FieldSpec Pro spectrophotometer and standardized using a white spectrolon surface. The area of the trough between wavelengths of 650 and $700 \mathrm{~nm}$ provides the best estimate of sedimentary chlorophyll- $a$. All spectral work was undertaken in the laboratory of Benoit Rivard at the University of Alberta.

\section{Results $^{1}$}

\section{Chronology}

The chronology for the SS49 Russian cores is based upon eight bulk sediment radiocarbon dates and one paired wood macrofossil date. From the macrofossil it was possible to determine a lake-specific carbon reservoir age of $334{ }^{14} \mathrm{C}$ years. This was subtracted from all remaining SS49 radiocarbon dates. An age model was built using a monotone Hermite cubic spline interpolation between dates following Fritsch and Carlson (1980) wherein all age reversals were removed (Figure 2).

The chronology for the SS16 Russian cores is based upon seven radiocarbon dates: six bulk dates

1. All of the data from Lakes SS16, SS32, and SS49 presented in this study are available online through the World Data Center for paleoclimatology - http://www.ncdc.noaa.gov/paleo/pubs/jopl2012arctic/jopl2012arctic.html 
Figure 1. Location map showing (A) the study area within Greenland and the location of GRIP ice core records referred to in the text; and (B) the three study lakes in West Greenland, the towns of Sisimiut and Kangerlussuaq, and Braya Sø.
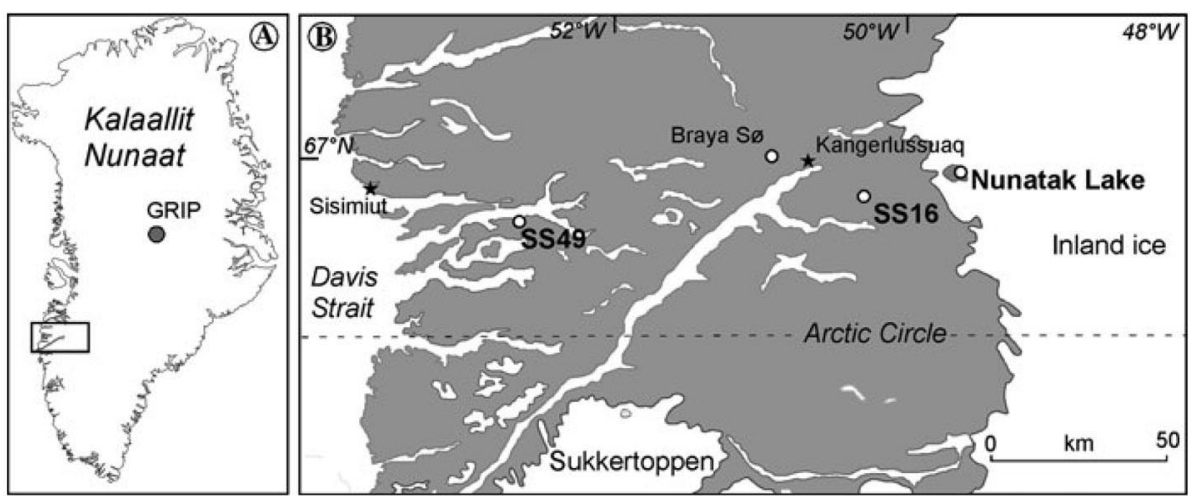

and one paired terrestrial plant macrofossil. In this sediment record, there is no apparent radiocarbon reservoir age, and no corrections were used. An age model was built using a monotone Hermite cubic spline interpolation as in SS49 (Figure 2).

The chronology for Nunatak Lake (SS32) is the least precise of the three lakes. The Russian core chronology is anchored by four ${ }^{14} \mathrm{C}$ ages on humic acid and one paired humin date. Humic acids are considered to be the most faithful ${ }^{14} \mathrm{C}$ target in sediments where macrofossils are completely absent (Abbott and Stafford 1996; Wolfe et al. 2004). The offset between the younger base-insoluble fraction (humin) and the humic acid dates was $230{ }^{14} \mathrm{C}$ years. This correction was applied to the remaining dates, and a linear age model was fit to the data (Figure 2). Because the top of the sediment taken with the Russian sampler from Nunatak Lake was lost during coring, a surface gravity core was used to complete the sedimentary sequence from the lake. However, unlike the other lakes where a clear overlap with either the OM or chlorophyll-a stratigraphies made correlating cores possible, correlation between the two Nunatak Lake cores was not possible. This is likely due to a lack of overlap between the two records. However, all proxy values are nearly identical on either side of the hiatus, which suggests that the gap may be only a few centimeters. An extrapolation of the age depth model to the base of the ${ }^{210} \mathrm{~Pb}$-dated portion produces no hiatus. However, care must be taken in the interpretation of exact dates for that period.

\section{Coastal record (SS49)}

The sedimentary record from the coastal lake SS49 spans the last $10 \mathrm{ka}$ BP (cal years) (Figure 3). The base of the core is composed of clay that quickly grades to faintly laminated gyttja and massive brown gyttja in the uppermost $70 \mathrm{~cm}(2.5 \mathrm{ka} \mathrm{BP})$. The percentage of total organic carbon (TOC) reflects the lithological changes: minimum values occur at the base of the core, then reach a maximum (24\%) at $8.0 \mathrm{ka} \mathrm{BP}$ with subsequent high-frequency variability until $3.5 \mathrm{ka} \mathrm{BP}$. Chlorophyll- $a$ content is lowest in the oldest sediments and rapidly reaches a maximum by $8.0 \mathrm{ka}$ BP. Thereafter, the inferred chlorophyll- $a$ declines to a minimum between 3.5 and $1.5 \mathrm{ka} \mathrm{BP}$, with a slight increase to the present.

Diatoms from 116 species, representing 20 genera $(>1 \%)$ were identified from the sediments at SS49 (Figures 4 \& 5). The oldest diatom zone (9.5$9.2 \mathrm{ka} \mathrm{BP}$ ) contains $\sim 45 \%$ Fragilaria pinnata (=Staurosirella pinnata) together with other, mostly benthic, taxa such as Fragilaria gracilis, Cymbella descripta (=Encyonopsis descripta), C. microcephala (=Encyonopsis microcephala), and Achnanthes minutissima (=Achnanthidium minutissimum). In zone 2, from 9.2 to $6.9 \mathrm{ka} \mathrm{BP}$, the Cyclotella stelligera (=Discostella stelligera) complex dominates. Zone 3 (6.9$5.3 \mathrm{kaBP}$ ) marks its replacement by Brachysira vitrea, and to a lesser extent, B. zellensis, which dominate the assemblage until c. $5.3 \mathrm{ka}$ BP. Since then (zone 4), the flora is dominated by the Cyclotella rossii complex and Fragilaria exigua (=Fragilariforma exiguiforma), and to a lesser extent, Achnanthes pusilla (=Rossithidium pusillum), A. minutissima, Nitzschia fonticola, and Pinnularia interrupta, as well as by diagnostic acidophilous taxa, such as Frustulia rhomboides, variants of Aulacoseira lirata, and $A u$ lacoseira alpigena.

Inland record (SS16)

The paleolimnological record from SS16 begins at $8.5 \mathrm{ka} \mathrm{BP}$ (Figure 6). Initial lake sediments from 

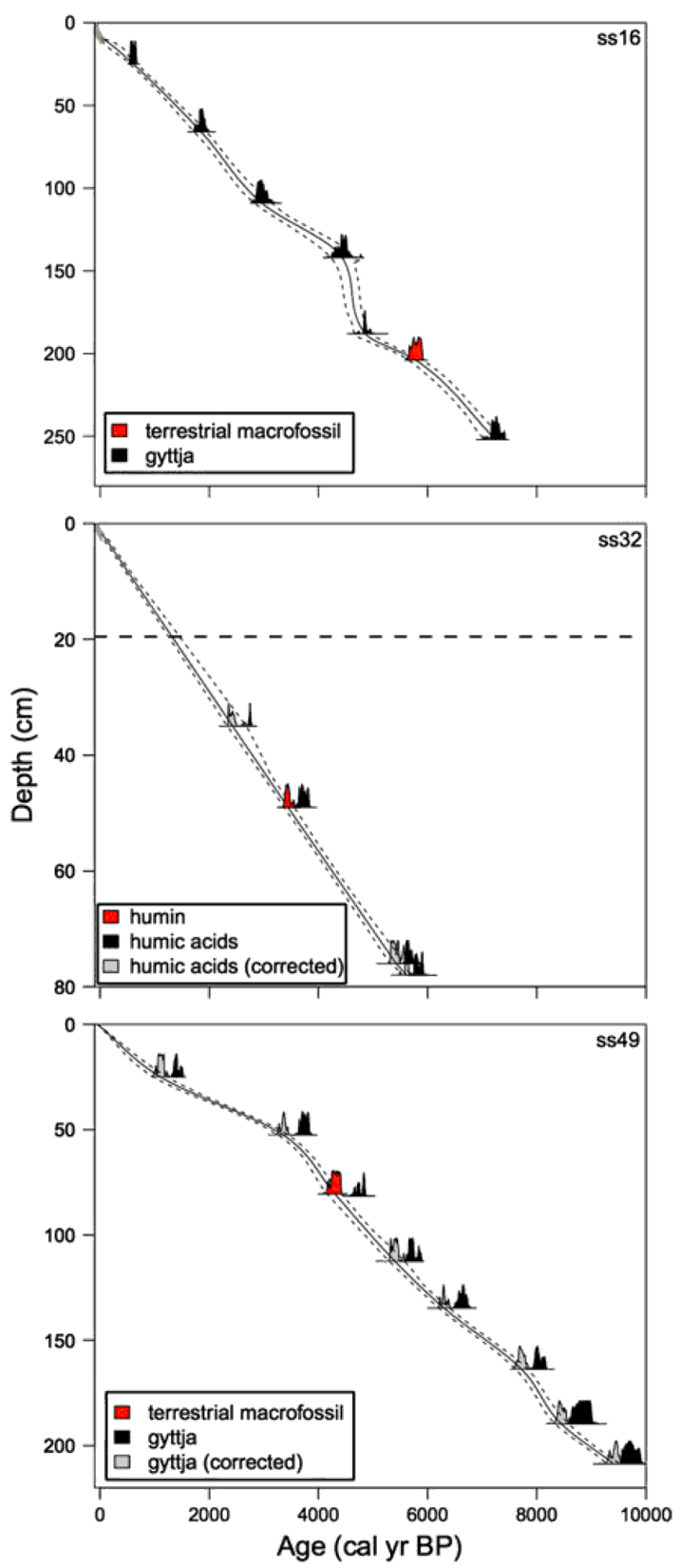

Figure 2. Age-depth models for SS16, SS32 (Nunatak Lake), and SS49 and the calibrated-age probability density distributions for each radiocarbon date. The $90 \%$ confidence interval is shown by a dashed line. Different materials (humin, humic acids, plant remains, and gyttja) are indicated by different shading. The horizontal dashed line on SS32 indicates the core break.

SS16 are clayey and low in organic-matter content (10\% OM). The loss-on-ignition values rise sharply by $7 \mathrm{ka} \mathrm{BP}$ to between 30 and $45 \%$, and the sedi- ments become distinctly laminated. In the centuries before $1850 \mathrm{AD}$, the $\mathrm{OM}$ decreases to the lowest values of the late Holocene, followed by a Holocene maximum at the present.

The magnetic susceptibility (MS) profile displays a trend comparable to OM (Figure 6). MS is a measure of magnetic mineral (iron) content of the sediment, often used as a proxy for catchment inputs via either runoff or eolian inputs. The highest values at SS16 are in the earliest Holocene, and likely represent a period of landscape instability that lasts approximately until $6.5 \mathrm{ka} \mathrm{BP}$, when $B$. nana heaths were established in West Greenland and cryosols began to develop (Fredskild 1983). MS values are low throughout the mid- and late-Holocene sediments, until approximately 500 years ago when they increase, suggesting a renewal of eolian activity during the Little Ice Age.

The diatom assemblage from SS16 reflects the complexity of Holocene lake development in West Greenland (Figure 6). In total, 163 species belonging to 25 genera were identified. At the beginning of the record (zone 1: 8.4-6.5 ka BP), diatom concentrations are variable, and species are represented by alkaphilous benthic taxa (i.e. Fragilaria sensu lato). From 6.5 to 4 ka BP (zone 2), diatoms are episodically absent from the sediments, but the existing diatoms (dominated by small benthic Fragilaria s.l.) show no signs of dissolution. At the beginning of zone 3 (4-0.5 ka BP), small benthic taxa in the lake are replaced by a largely planktonic flora composed of complexes of both Cyclotella stelligera and C. rossii, and Fragilaria gracilis, as well as lesser percentages of small benthic Fragilaria exigua, Achnanthes minutissima, and A. pusilla. Zone 4 (0.5-0 ka BP) is marked by a peak in the Cyclotella stelligera complex $(\sim 80 \%)$, as well as the arrival and rise of planktonic Fragilaria tenera complex.

Nunatak Lake record (SS32)

The stratigraphic record from Nunatak Lake SS32 is the shortest of the three lakes and spans approximately $5.6 \mathrm{ka}$ (Figure 7). The bottom of the core contains coarse sand, which is immediately followed by greyish gyttja between 5.5 and $5.1 \mathrm{ka}$ BP. The lower organic-rich section is interrupted by a clay layer containing coarse sand lenses (5.1$4.8 \mathrm{ka} \mathrm{BP})$, which then grades into increasingly organic-rich sediments from $4.8 \mathrm{ka} \mathrm{BP}$ until the pres- 


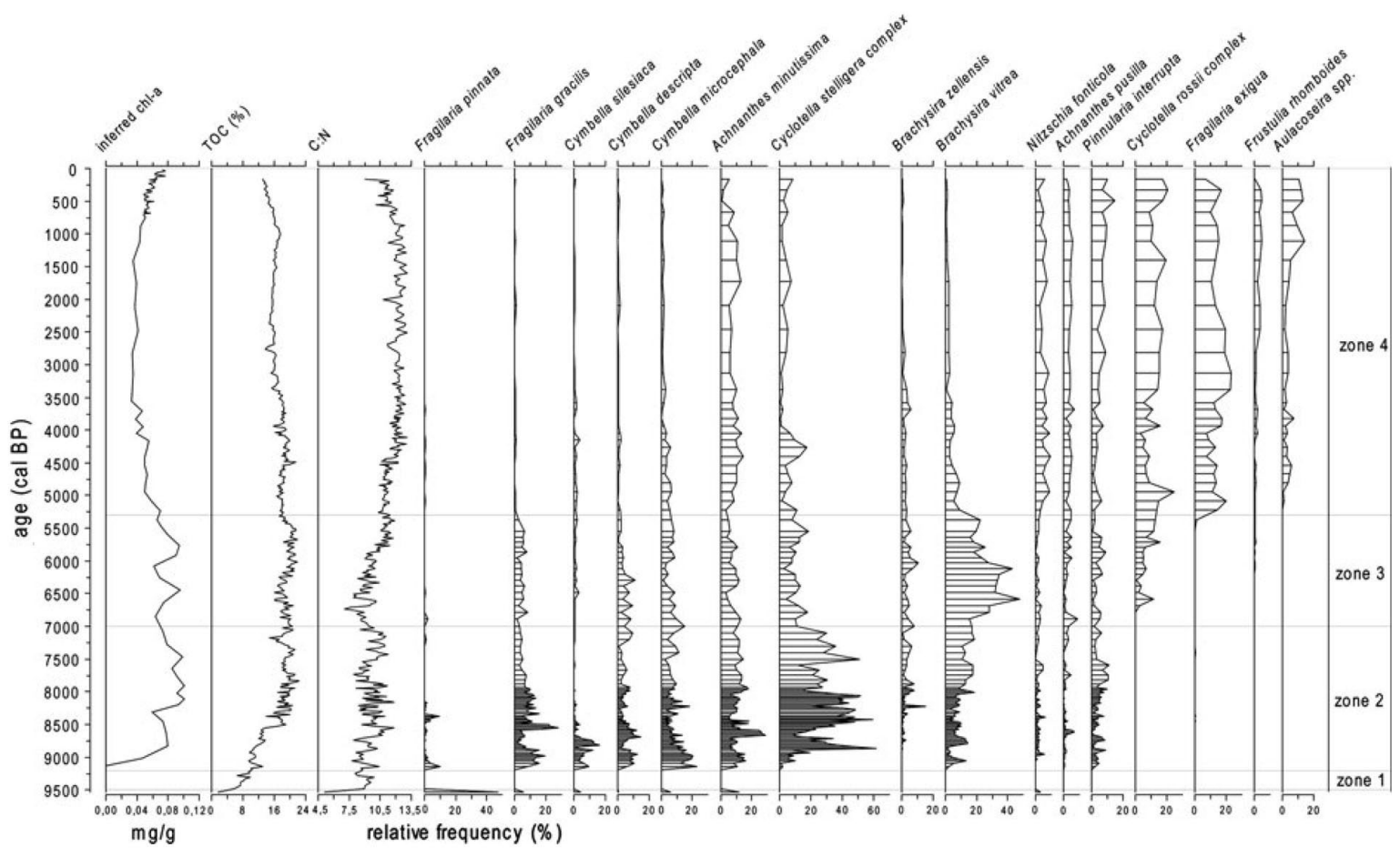

Figure 3. Diatom stratigraphy from SS49 showing sediment inferred chlorophyll- $a$, total organic carbon (TOC), carbon to nitrogen $(\mathrm{C}: \mathrm{N})$ ratio, and the most important diatom taxa from the core.

ent. This suggests an incursion of glacier ice into the catchment early in the lake history and is supported by glaciological evidence documenting advancing ice margins during the early Neoglaciation (Kelly 1985; van Tatenhove et al. 1996). The OM and chlorophyll- $a$ profiles parallel these changes, with early high values, followed suddenly by a period of low production, and steadily increasing values from approximately $5 \mathrm{ka} \mathrm{BP}$.

Diatoms from 170 species and 23 genera were identified from Nunatak Lake sediments. Diatom concentrations mimic the $\mathrm{OM}$ profile, with peaks centered at 5.4, 4.5, and $2.2 \mathrm{ka} \mathrm{BP}$ (Figure 7). The diatom stratigraphy is divided into four zones, which follow some of the successional patterns in the other two lakes, with several notable exceptions. In zone 1 (5.6-4.3 ka BP), the earliest diverse assemblage is characterized by high species turnover. The oldest diatoms are Nitzschia fonticola and Achnanthes acares. Rapidly thereafter, small benthic alkaliphilous Fragilaria taxa (F. pinnata, F. pseudoconstruens (=Pseudostaurosira pseudoconstruens), and F. brevistriata (=Pseudostaurosira brevistriata) are the most abundant diatoms in this lower group. Other benthic taxa alternately dominate these clay-rich sediments: Amphora fogediana, Cymbella microcephala, Stauroneis anceps, Navicula exilis. As the sediments become more organic, Navicula laevissima (=Sellaphora laevissima) and N. seminulum (=Sellaphora seminulum) have brief peaks in relative abundance. Diatom concentration is low during this period of high species turnover, and such high beta-diversity could be the result of benthic patchiness (cf. Wolfe 1996). Zone 2 (4.3-2.3 ka BP), is marked by the establishment of a planktonic assemblage dominated by Cyclotella stelligera complex, C. bodanica (=Puncticulata bodanica), and Fragilaria nanana. Zone $3(2.3-1.2 \mathrm{ka} \mathrm{BP})$ is distinguished by the arrival and dominance of Asterionella formosa, which reaches a maximum (>60 \%) c. 2 ka BP; a lesser peak of Aulacoseira alpigena also occurs during this period. In the last $1.2 \mathrm{ka} \mathrm{BP}$ (zone 4), complexes of both Cyclotella rossii and $C$. stelligera reach their present maxima.

\section{Chronosequences}

The chronosequences for the three West Greenland sedimentary sequences each traverses the primary axis (9.6\% variance) from negative to pos- 

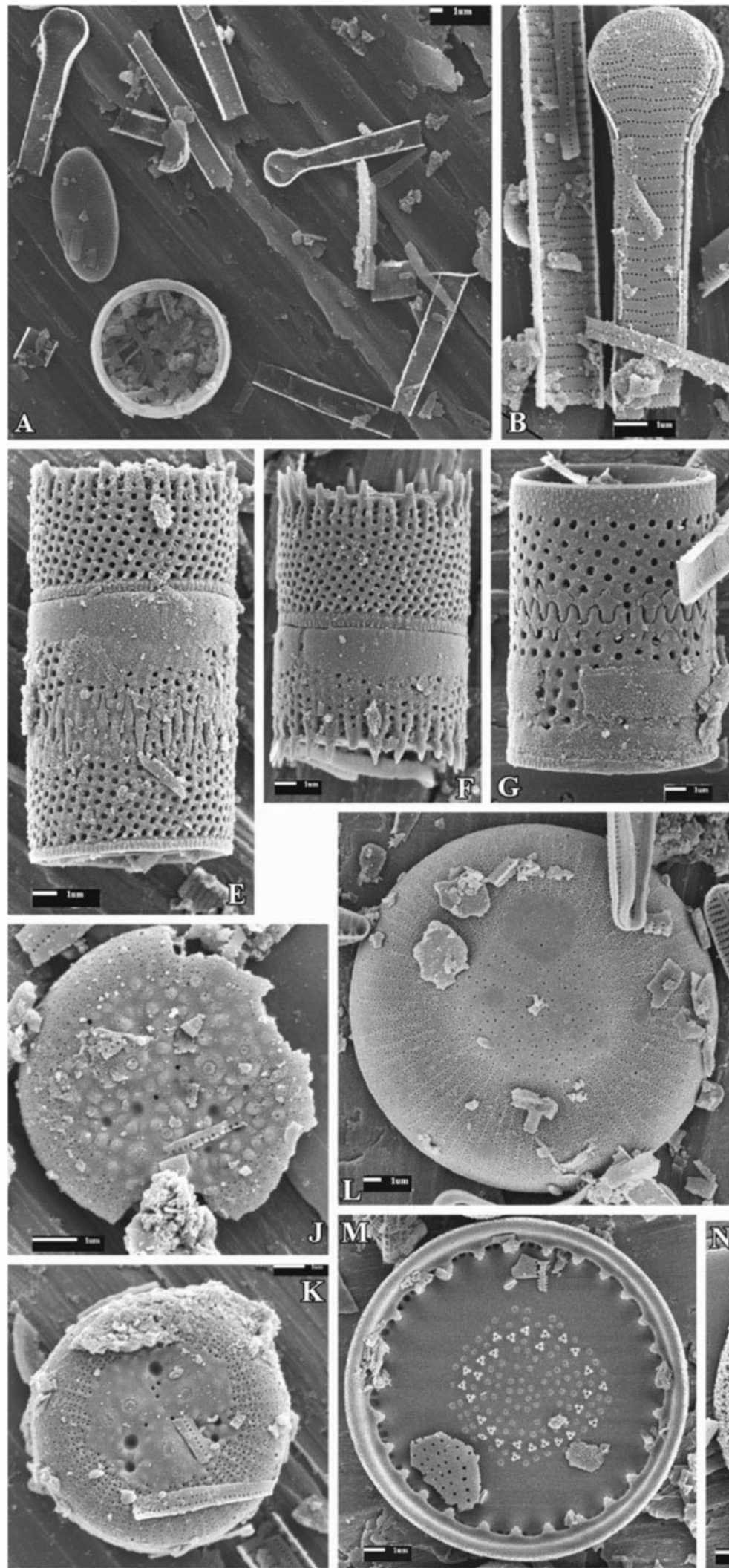
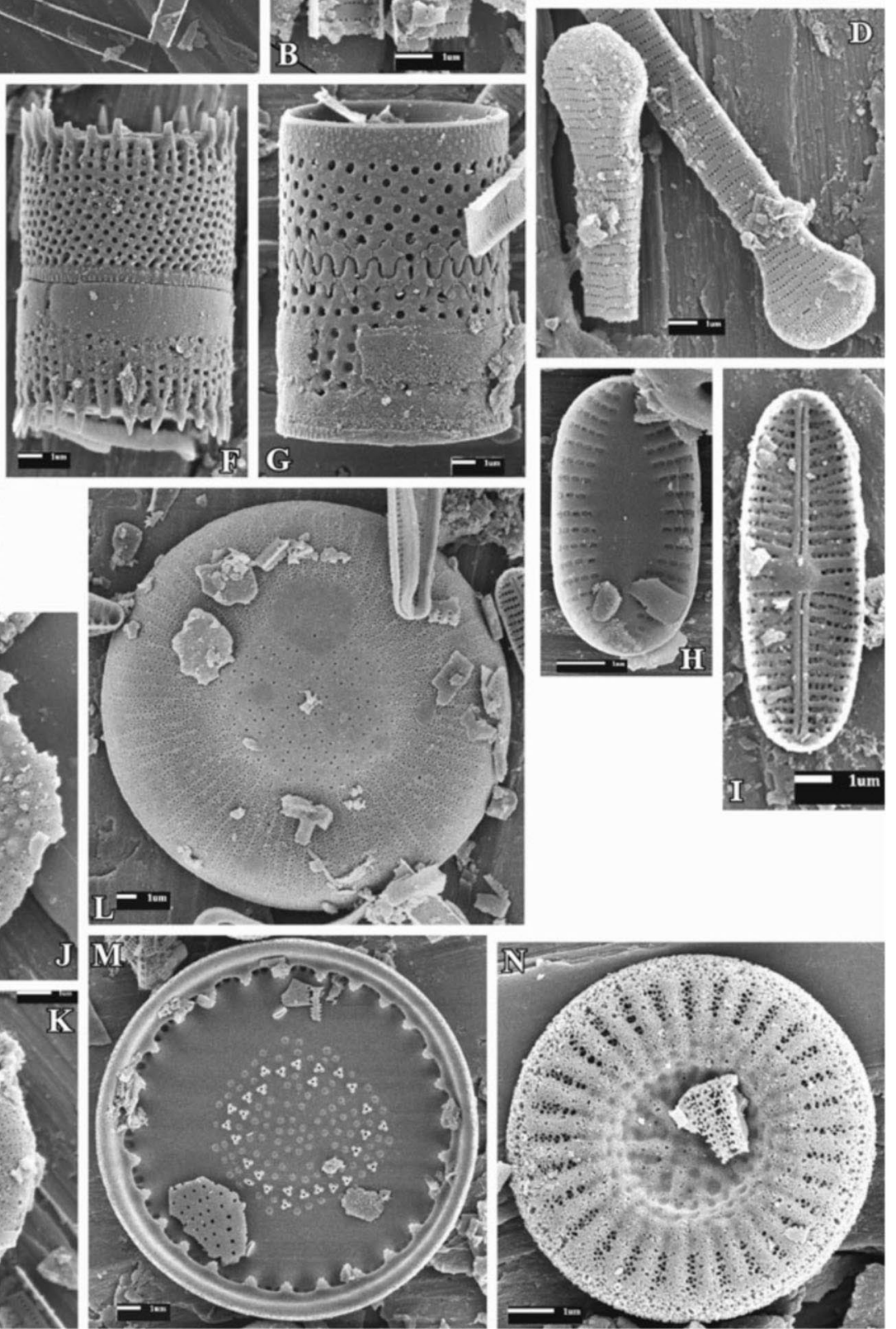

Figure 4.

SEM images of

West Green-

land diatoms:

a) assemblage

overview

from SS32

(Nunatak

Lake),

b-d) Asterio-

nella formosa,

e-f) Aulaco-

seira alpigena,

g) Aulacoseira

lirata,

h) Achnan-

thes didyma

(=Psammothidium didymum),

i) Achnanthes

pusilla,

j-m) Cyclotella tripartita-co-

mensis-ocellatarossii group referred to as the "Cyclotella rossii complex," and

n) Cyclotella stelligera. 
itive (Figure 8). This axis is primarily driven by the $\mathrm{pH}$ gradient, which alone explains the greatest amount of variance in the dataset $(8.6 \%$; Perren 2007) but is strongly correlated with other limnological variables such as conductivity, alkalinity, $\mathrm{Ca}^{2+}, \mathrm{Mg}^{2+}$, and total phosphorus (TP), as well as longitude. This axis therefore reflects the gradient between the maritime, dilute, low $\mathrm{pH}$ lakes at the coast and the continental, evaporatively enriched, alkaline lakes of the interior near the ice margin (see Anderson et al. 2001 for a discussion of West Greenland limnology). Thus, the general Holocene trend of the lakes is a long-term decline primarily in $\mathrm{pH}$ (acidification), as well as in TP (oligotrophication). The secondary axis (5.5\% variance) is driven primarily by the depth gradient in the lakes, which likely reflects the changes in the relative importance of planktonic diatoms in the West Greenland lake calibration set. Figure 9 shows the trajectories of the cores plotted against time with good agreement between the three records both in terms of timing of shifts and direction over the course of the Holocene relative to the Holocene June insolation for $60^{\circ} \mathrm{N}$.

\section{Discussion}

Holocene lake evolution

Lakes in glaciated northern temperate latitudes (e.g. Alaska, Labrador, Sweden) commonly become more acidic (Renberg 1990a; Bigler et al. 2002) and oligotrophic (Engstrom and Hansen 1985; Engstrom et al. 2000) with time. Receding glaciers that have traversed base-rich terrane leave behind catchments with high concentrations of base cations in surface till that buffer catchment and atmospheric acidity in the initial period following deglaciation. As the landscape stabilizes, organic-rich soils develop, and forests grow and utilize nutrients. Over time, these edaphic processes reduce catchment inputs of alkalinity and nutrients to lakes and other water bodies and increase fluxes of DOC, resulting in a lake with lower $\mathrm{pH}$, fewer nutrients, and higher DOC (Whitehead et al. 1989; Engstrom et al. 2000). These processes also affect the ontogeny of lakes in West Greenland, as documented by Fredskild (1983) and by the chronosequences presented here (Figure 8), in which the lake trajectories show declining $\mathrm{pH}$ (acidification) and TP (oligotrophication) trends over the course of the Holocene based on a comparison with gradients in contemporary lakes.

Each of the three lakes experienced a similar Holocene developmental pathway. Early colonizers, such as Fragilaria pinnata and other Fragilaria s.l. spp., and small, raphid, benthic alkaliphils (Amphora, Cymbella, Navicula, and Achnanthes spp.) characterized the initial deglacial, minerogenic sediments. As the surrounding landscape stabilized, inorganic sedimentation decreased, and a predominantly planktonic flora consisting of $\mathrm{Cy}$ clotella rossii and/or C. stelligera complex developed. The benthic component of this assemblage was composed of small Achnanthes spp., Fragilaria exigua, Brachysira spp., and Pinnularia interrupta. Eventually, planktonic species of Fragilaria nanana/ tenera and Aulacoseira alpigena and/or A. lirata may have appeared with other benthic acidophilous taxa.

While variations among individual taxa and their rates of expansion vary geographically within the study area, the basic sequence of small benthic Fragilaria[Cyclotella \pm Aulacoseira is also recognized in many postglacial records from glaciated regions of the Northern Hemisphere. Indeed, the West Greenland diatom successional trajectory is similar to Holocene sequences from New England (Whitehead et al. 1989), Sweden (Bigler et al. 2002), Alaska (Fritz et al. 2004), East Greenland (Cremer et al. 2001), and Baffin Island (Michelutti et al. 2007). Truncated versions of this sequence (Fragilaria pinnata $>$ Cyclotella) can also be found in the High Arctic, where diatom floras are newly established as a result of twentieth century climate change in onceperennially frozen lakes (Perren et al. 2003). This sequence has also been noted over the course of multiple interglacials on Baffin Island (Wilson et al. 2012). The ubiquitous nature of this diatom successional sequence suggests that it should be regarded as a template for ontogeny not only in glaciated regions with a humid to sub-humid climate, but also in semi-arid to arid regions such as West Greenland. 

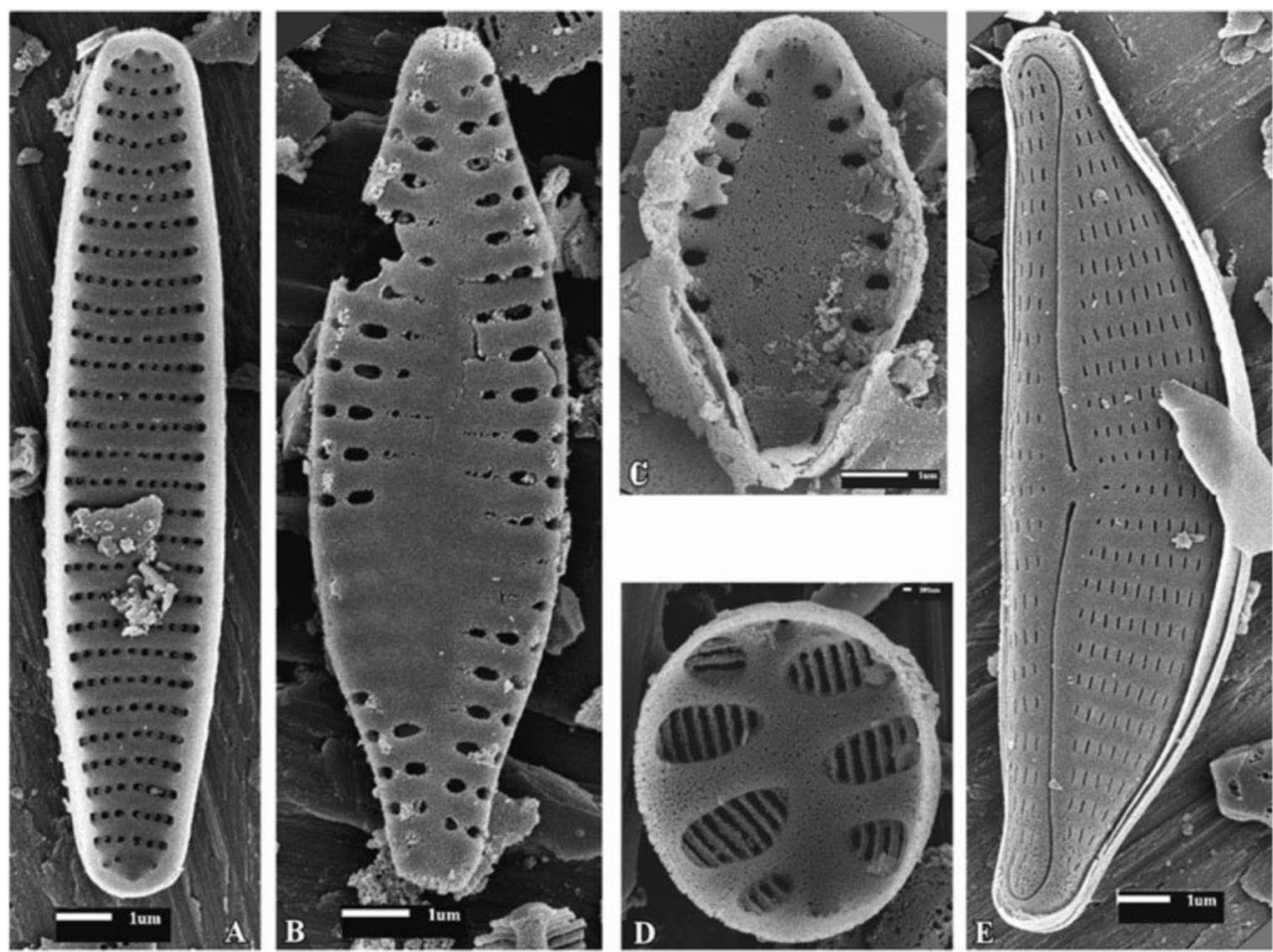

Figure 5.

SEM images of common West Greenland benthic diatoms:

a) Fragilaria exigua, b-c) F. brevistriata,

d) F. pinnata,

e) Cymbella cf. minuta

(=Encyonema minutum),

f) F. construens var. venter

(=Staurosira construens var. venter),

g) F. pinnata,

h) F. pseudoconstruens,

i) F. pinnata in girdle view

undergoing cellular divi-

sion, and

j) girdle view of

three frustules of $F$.

pseudoconstruens.
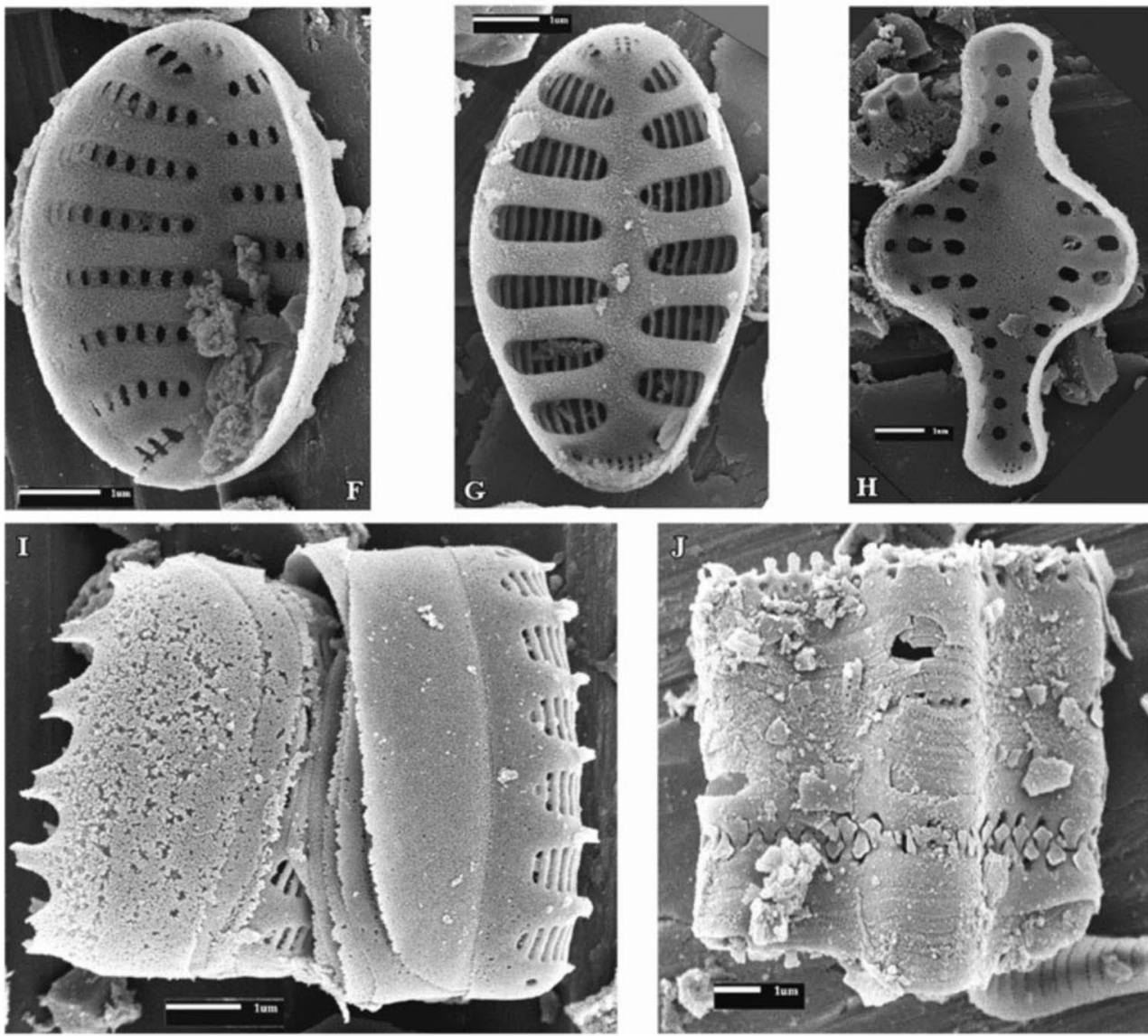


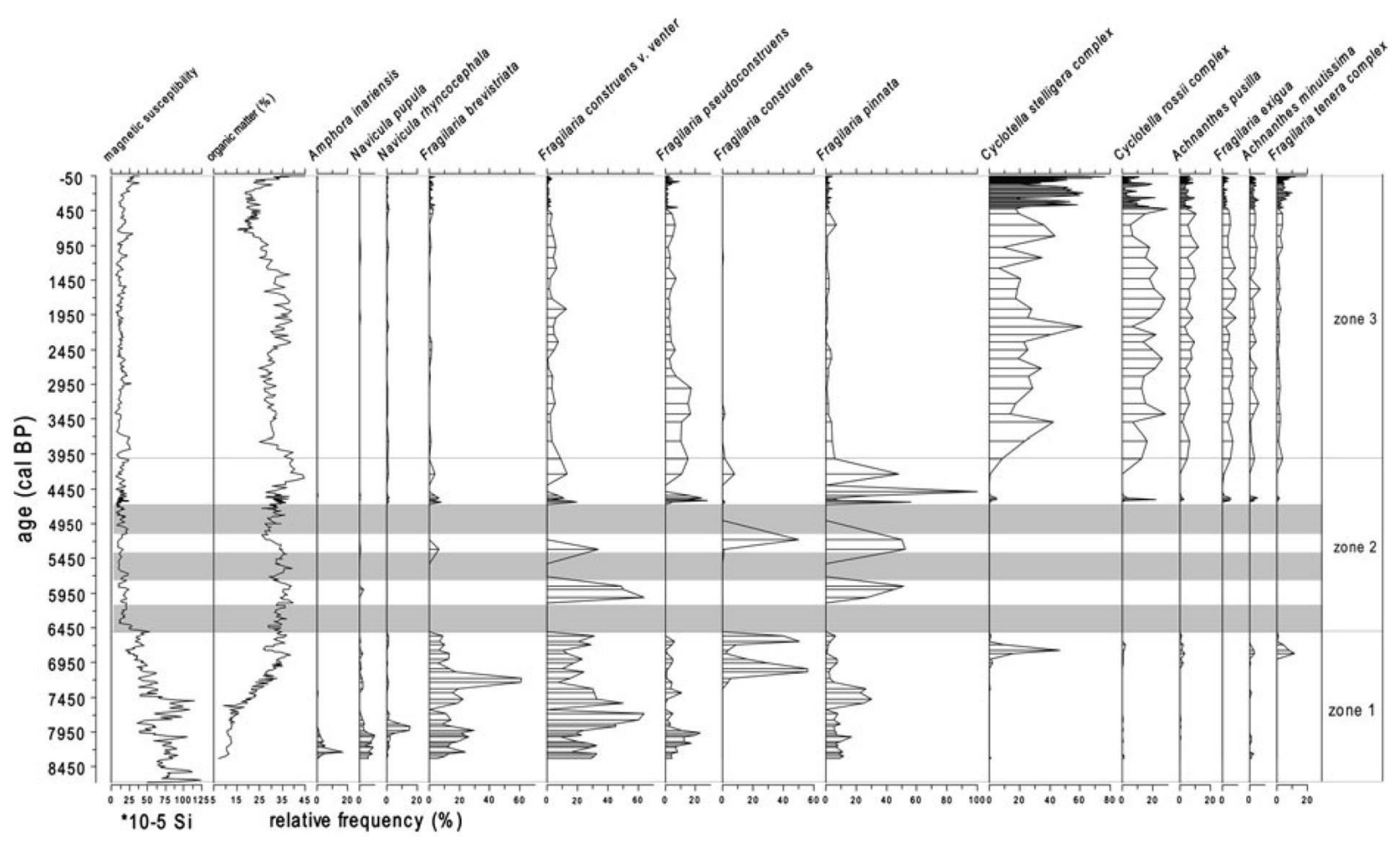

Figure 6. Diatom stratigraphy from SS16 showing magnetic susceptibility, organic-matter content, and the most important diatom taxa from the core. Grey bands mark intervals devoid of diatoms.

Regional variability of West Greenland lakes

The influence of Holocene climate change on lake development in West Greenland varied from the coast to the ice-sheet margin. Near the coast, persistent fog, low summer temperatures, higher precipitation, and peat development all likely contribute to a trend of increasing acidification and oligotrophication. The build up of heaths and soils reduces the impact of climate variations as they are not magnified by runoff or by eolian activity as they would be in an unvegetated catchment. Maritime conditions also buffer the lake from climate extremes, dampening the lake-climate signal and thus creating a long secular trend in lake development at the coastal lake SS49.

Inland, however, lake development is more tightly controlled by climate, specifically by effective moisture. At SS16, two prominent features interrupt Holocene lake developmental trends of increasing planktonic abundance and decreasing $\mathrm{pH}$ and nutrients over time: 1) extreme variability and the intermittent absence of diatoms between 6.5$4.5 \mathrm{ka} \mathrm{BP}$, and 2) the step-wise transition to a stable planktonic diatom flora $\sim 4 \mathrm{ka} B P$. The reason for the absence of diatoms in SS16 is unknown; however, aquatic invertebrates Lepidurus arcticus and Daphnia pulex also disappear at this time, and plant remains of Chara and Nitella are replaced by mesotrophic moss-dominated fen species (Heggen et al. 2010). Other lake records from West Greenland document profound aridity (a reduction of 80 $\mathrm{mm} \mathrm{yr}^{-1}$ of precipitation relative to today) and high summer temperatures $\left(+2-3{ }^{\circ} \mathrm{C}\right)$ during this period (Aebly and Fritz 2009), suggesting a lowering of lake level and the growth of a macrophyte-dominated productive fen, which may have precluded diatom proliferation and/or preservation.

Sensitivity to effective moisture changes also appears to control the diatom stratigraphy at SS16 in the late Holocene. The reappearance of diatoms c. $4.5 \mathrm{ka} \mathrm{BP}$ and the establishment of a planktonic flora is correlated with the rapid onset of cooler, moister conditions of the Neoglaciation. Beginning 


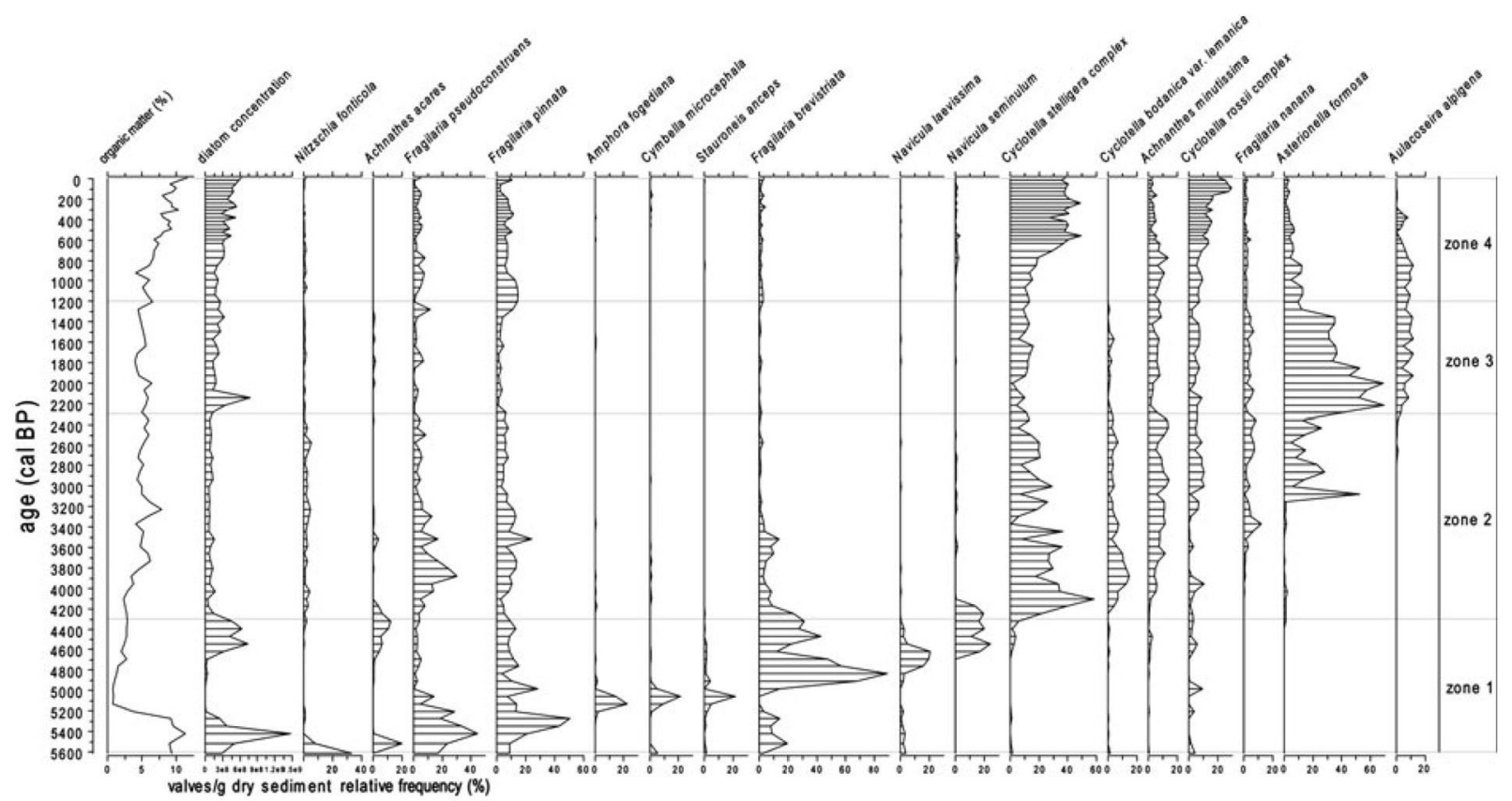

Figure 7. Diatom stratigraphy from Nunatak Lake showing organic-matter content, diatom concentration, and the most important diatom taxa from the core.

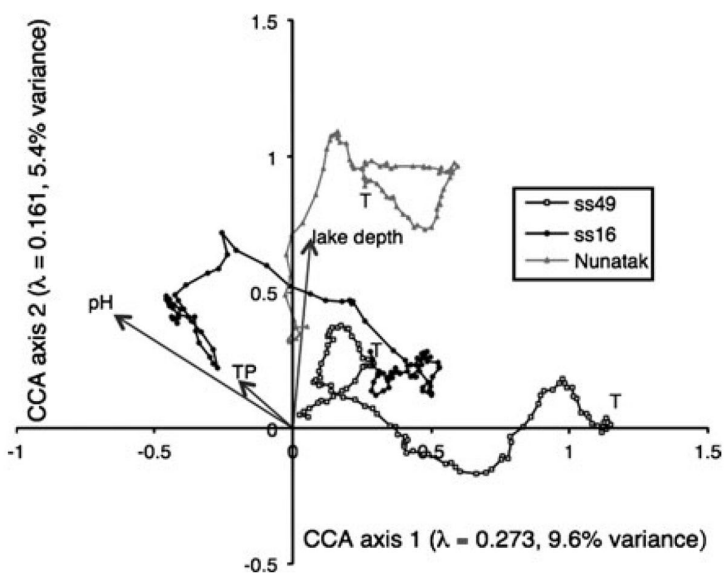

Figure 8. Chronosequences of the three study lakes passively plotted on a 40-lake regional CCA from Perren (2007). Forward selected environmental variables are shown by arrows. " $\mathrm{T}$ " indicates core tops.

c. $4.5 \mathrm{ka} \mathrm{BP}$, records from nearby salt lakes document a switch to higher effective precipitation marked by low DI-conductivity (McGowan et al. 2003), $\delta^{18} \mathrm{O}$ isotopic excursions (Anderson and Leng 2004), and higher lake levels (Aebly and Fritz 2009). The shift is also concurrent with deuteriuminferred changes to cooler and moister weather in Greenland (Masson-Delmotte et al. 2005) and with peat development in West Greenland (Fredskild 1985). The link between the dominance of diatom phytoplankton, particularly species in the genus Cyclotella, and cooler conditions of the Neoglacial period is not simple. While increased acidification clearly plays some role in driving this shift, as diatom-inferred $\mathrm{pH}$ during this period continued to decrease ( $\sim 0.3 \mathrm{pH}$ units; Perren 2007), the shift to a plankton-dominated flora suggests a fundamental change in habitat availability and use in the lake.

Increases in the presence of small-sized Cyclotella over other larger planktonic species are typically associated with warmer conditions and with recent climate warming (Rühland et al. 2008), as small phytoplankton benefit from increased stratification and reduced N:P ratios (Winder et al. 2009). However, in the case of the shift from a benthicto planktonic-dominated diatom flora, the inverse may be true: cooler summer temperatures may decrease the strength of the temperature gradient in the water column, which allows for greater turbulence in the water column, decreasing phytoplankton loss from the upper water column and enhancing nutrient mixing.

The Holocene developmental record from Nunatak Lake, SS32, is strongly influenced by climatic factors. The lake was established at the onset of the 


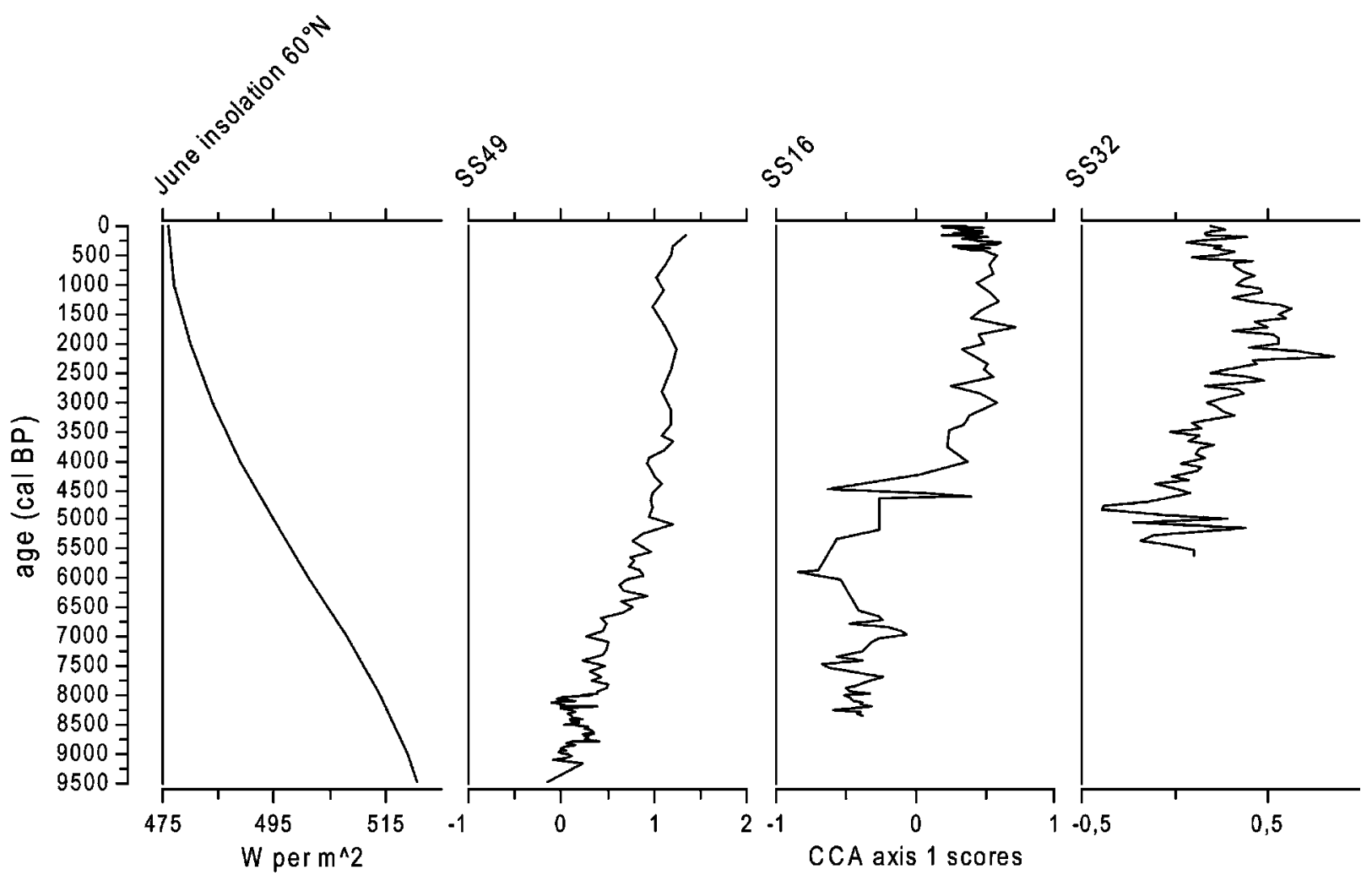

Figure 9. Chronosequence CCA axis 1 scores for the three lakes plotted against time and June insolation at $60^{\circ} \mathrm{N}($ Berger and Loutre 1991).

Neoglaciation, when local glaciers were at their Holocene minima, tens of kilometers behind the present margin (van Tatenhove et al. 1996). Over the following several centuries, as temperatures declined and moisture levels rose, the Greenland Ice Sheet advanced around the lake. The clay and coarse sand layers near the bottom of the core testify to some local incursion of ice and/or meltwater at this time. This unstable period in the lake history is characterized by large changes in benthic diatom taxa (Figure 5). Beginning c. $4.3 \mathrm{ka} \mathrm{BP}$, a more stable, predominantly planktonic flora developed. Records from sandar at the ice margin suggest that local eolian activity was at its highest c. 0.5-0 ka BP and before $3.5 \mathrm{ka} \mathrm{BP}$ (Willemse et al. 2003). Both the increased windiness and eolian sediment loads may have led to the dominance of Cyclotella stelligera during these periods at Nunatak Lake by enhancing mixing and water column turbulence.

The most striking feature of Nunatak Lake record is the appearance of significant proportions of Asterionella formosa c. 2 ka BP (Figure 7). A. formosa is a mesotrophic planktonic diatom (Figure $4 b-d$ ), which is often associated with anthropogenic eutrophication (Bradbury 1975); it is hitherto unreported from remote Arctic lakes before the 20th Century. A. formosa has high nutrient requirements, specifically high N:P resource ratios (Saros et al. 2005). For this reason, its occurrence here is anomalous. However, current total N:P ratios from Nunantak Lake are considerably higher than those from either SS49 or SS16, where Asterionella is absent (Table 1). Some degree of localized nutrient loading, particularly with respect to inorganic $\mathrm{N}$, may have been associated with oscillations of the Greenland Ice Sheet during the late Holocene. Although the exact mechanism remains unspecified, it is clear that the N:P nutrient balance was tipped in favor of $A$. formosa blooms at Nunatak Lake alone, since lakes farther from the ice sheet do not record this diatom.

The geographically variable response of lakes to Holocene climatic forcing highlights the importance of local factors in limnological responses to climate change (Fritz et al. 2004). In this region, 
Table 2. Radiocarbon dates, materials, and calibrated ages.

\begin{tabular}{lllll}
\hline Lab number & Depth $(\mathrm{cm})$ & Material & ${ }^{14}$ C age BP & $\begin{array}{l}\text { Median calibrated } \\
\text { age BP }\end{array}$ \\
\hline SS49 & & & \\
AA50045 & $25-26$ & Gyttja & $1516 \pm 37$ & 1399 \\
AA50046 & $52.5-53.5$ & Gyttja & $3465 \pm 41$ & 3743 \\
AA50053 & $80.5-81.5$ & Wood & $3872 \pm 42$ & 4306 \\
AA50047 & $81.5-82.5$ & Gyttja & $4232 \pm 43$ & 4753 \\
AA50048 & $112.5-113.5$ & Gyttja & $4988 \pm 44$ & 5717 \\
AA50049 & $134.7-135.7$ & Gyttja & $5830 \pm 47$ & 6641 \\
AA50050 & $163.7-164.7$ & Gyttja & $7212 \pm 55$ & 8028 \\
AA50051 & $189.7-190.7$ & Gyttja & $7975 \pm 72$ & 8834 \\
AA50052 & $208.7-209.7$ & Gyttja & $8739 \pm 57$ & 9724 \\
SS32 (Nunatak Lake) & & & \\
UA-32355 & $35-36$ & Humic acid & $2610 \pm 35$ & 2746 \\
UA-32356 & $49-50$ & Humin & $3220 \pm 40$ & 3437 \\
UA-32357 & $49-50$ & Humic acid & $3450 \pm 40$ & 3718 \\
UA-32358 & $76-77$ & Humic acid & $4920 \pm 45$ & 5648 \\
UA-32359 & $78-79$ & Humic acid & $5105 \pm 40$ & 5821 \\
SS16 & & & \\
AAR-5936 & $25-26$ & Gyttja & $625 \pm 40$ & 602 \\
AAR-5935 & $66-67$ & Gyttja & $1910 \pm 45$ & 1855 \\
AAR-5934 & $109-110$ & Gyttja & $2840 \pm 50$ & 2954 \\
AAR-5933 & $142-143$ & Gyttja & $3975 \pm 60$ & 4442 \\
AAR-5932 & $188-189$ & Gyttja & $4285 \pm 45$ & 4855 \\
AAR-5931 & $204-205$ & Terrestrial plant & $5035 \pm 55$ & 5793 \\
AAR-5930 & $252-253$ & Gyttja & $6320 \pm 65$ & 7251 \\
\hline
\end{tabular}

edaphic processes and eolian inputs, as well as spatially variable effective moisture and changing wind regimes can affect the response of a lake to a given climatic forcing and lead to differential responses to climate change, as is seen in the two inland records from West Greenland.

\section{Holocene climate trends}

Despite the time-transgressive attributes of the three Holocene lake records in terms of diatom succession, the synchronous timing of species shifts (i.e. benthic Fragilaria spp. to planktonic Cyclotella spp. $\sim 4.5 \mathrm{ka} \mathrm{BP}$ ) suggests that climate exerts a first-order control on diatom assemblages. Three main periods can be identified: an early warm, dry period that lasted until $5.6 \mathrm{ka} \mathrm{BP}$, a shift into the cooler, wetter conditions of the Neoglaciation that began at $\sim 4.5 \mathrm{ka}$ $\mathrm{BP}$, and a recent increase in aridity and eolian deposition and windiness beginning 1500 AD.
Several independent lines of evidence describe early Holocene climate in Greenland. Borehole temperatures and oxygen isotopes from the Greenland Ice Sheet suggest that temperatures were as much as $4{ }^{\circ} \mathrm{C}$ higher in the early Holocene, and reached a maximum between 8-6 ka BP (Dahl-Jensen et al. 1998; Vinther et al. 2009). Boreal mollusks document warm waters along the coast of West Greenland until c. 5.6 ka BP (Funder and Weidick 1991). Nearby lake levels and calcite isotopic records indicate extreme aridity from the early Holocene until $\sim 5.6 \mathrm{ka} \mathrm{BP}$, which may have been caused by a reduction of precipitation relative to modern by as much as 50\% (Anderson and Leng 2004; Aebly and Fritz 2009). At coastal lake SS49, the period until from 9 to $5.3 \mathrm{ka}$ BP is marked a rapid stabilization of the catchment and by the highest values of chlorophyll- $a$ suggesting that in-lake production was at its highest. At SS16, the early Holocene period is marked by an initial unstable catchment. Nunatak 
Lake, SS32, on the other hand was not established until $5.6 \mathrm{ka} \mathrm{BP}$, possibly delayed by negative effective moisture and dessicating winds at the margin of the Greenland Ice Sheet.

Neoglaciation in this region began between $\sim 5.6$ and $4.0 \mathrm{ka}$ BP. Locally, glaciers began readvancing in West Greenland c. 5 ka BP (Kelly 1985). At the coast, a sharp decrease in chlorophyll-a suggests a reduction in in-lake production at $\sim 5.3 \mathrm{ka} \mathrm{BP}$. At SS16, the modern plankton-dominated flora developed $\sim 4 \mathrm{ka}$ $\mathrm{BP}$, consistent with the onset of cooler, moister, perhaps windier conditions. Within the margin of the Inland Ice, SS32 was established at $5.6 \mathrm{ka}$ BP with a positive shift in effective moisture, and similarly, the transition to the modern plankton-dominated flora occurred $\sim 4.3 \mathrm{ka}$ BP. These shifts suggest that cooler conditions in the late Holocene drove higher moisture levels and increased water column mixing, which in turn established the current limnological conditions in West Greenland lakes.

Major inflections in the trajectories of lake development occurred at $\sim 0.5 \mathrm{ka} B P$ in both of the inland lakes. At SS16, this is documented by a large increase in Cyclotella stelligera and by a concomitant increase in MS. At Nunatak Lake, SS32, this shift is registered as a large step-wise increase in Cyclotella stelligera. These species shifts are also consistent with recent evidence for aridification in other West Greenland lake sediments (Perren et al. 2009) and with regional lake-level lowering (Aebly and Fritz 2009), as well as with a large increase in wind-derived calcium recorded in the Greenland Ice Sheet (O'Brien et al. 1995) and in eolian dust deposition in West Greenland (Willemse et al. 2003). Together, these shifts suggest that the cold, windy conditions of the Little Ice Age resulted in profound moisture balance changes and eolian reactivation near the West Greenland ice margin that are reflected in the species composition of the diatom flora.

\section{Conclusions}

Freshwater lakes in West Greenland undergo similar Holocene developmental pathways regardless of the age of the lake (Figure 8) (see also Massa et al. 2012). This sequence can be broadly defined as a transition from small benthic alkaphilous diatom taxa (e.g. Fragilaria sensu lato) to planktonic taxa (e.g., Cyclotella stelligera and/or rossii complexes) and, possibly, to more acidic planktonic taxa (e.g.
Aulacoseira lirata and/or alpigena). This sequence confirms that the pattern of natural Holocene acidification and oligotrophication (Ford 1990; Renberg 1990a; Fritz et al. 2004) is broadly applicable to lakes in glaciated regions and defines an envelope of variability for natural Holocene change in circumneutral Arctic lakes.

Although the ontogenetic pathways of each of the lakes are broadly similar, the timing of assemblage changes reflects differing limnological and catchment thresholds in response to climate. For this reason, individual lakes have largely individual histories, a pattern also observed in other regions (Fritz et al. 2004). Differences between the coastal record (SS49) and the two inland lake records (SS16 and SS32) cannot be attributed simply to differences in lake age, but rather to local climatic and edaphic features unique to the West Greenland landscape. At the coast, the response to Holocene climate variability is tempered by proximity to the ocean, as well as the influence of the higher precipitation on soils and vegetation, and lakes therefore document long-term Holocene acidification and oligotrophication. Farther inland, in contrast, the extreme continentality, negative effective moisture, wind, and dust enhance the sensitivity of these lakes to climatic change during the Holocene. These records highlight the importance of regional variability in paleoclimatic records and demonstrate the significance of non-linear responses inherent in ecological responses to climatic forcing.

Acknowledgments - This research was supported by NSF Grant 0081226 to SCF, and by a NSERC discovery grant to MSVD. ${ }^{210} \mathrm{~Pb}$ analyses were provided by Peter Appleby at the University of Liverpool. MS data were supplied by Amy Whittle (née Clarke) at the University of Liverpool. TOC and C:N data from SS49 were kindly provided by Billy D'Andrea. We thank Charly Massa for assistance with agedepth modeling and Alexander Wolfe for SEM images.

\section{References}

Abbott MB, Stafford TW Jr (1996) Radiocarbon geochemistry of modern and ancient arctic lake systems, Baffin Island, Canada. Quat Res 45:300-311

ACIA (2004) Impacts of a warming climate: Arctic climate impact assessment. Cambridge University Press, Cambridge

Aebly F, Fritz SC (2009) The paleohydrology of west Greenland for the past 8000 years. Holocene 19:91-104

Anderson NJ, Leng MJ (2004) Increased aridity during the early Holocene in West Greenland inferred from stable isotopes in laminated-lake sediments. Quat Sci Rev 23:841-849 
Anderson NJ, Harriman R, Ryves DB, Patrick ST (2001) Dominant factors controlling variability in the ionic composition of West Greenland lakes. Arct Antarct Alp Res 33:418-425

Anderson NJ, Brodersen KP, McGowan S, Johanssen L, Jeppesen E, Leng M (2008) Climate versus in-lake processes as controls on the development of community structure in a lowarctic lake (south-west Greenland). Ecosystems 11:307-324

Appleby PG, Oldfield F (1978) The calculation of ${ }^{210} \mathrm{~Pb}$ dates assuming a constant rate of supply of unsupported ${ }^{210} \mathrm{~Pb}$ to the sediment. Catena 5:1-8

Battarbee RW, Kneen MJ (1982) The use of electronically counted microspheres in absolute diatom analysis. Limnol Oceanogr 27:184-188

Berger A, Loutre MF (1991) Insolation values for the climate of the last 10 million years. Quat Sci Rev 10:297-318

Bigler C, Larocque I, Peglar SM, Birks HJB, Hall RI (2002) Quantitative multiproxy assessment of long-term patterns of Holocene environmental change from a small lake near Abisko, northern Sweden. Holocene 12:481-496

Blaauw M (2010) Methods and code for 'classical' age-modelling of radiocarbon sequences. Quat Geochron 5:512-518

Bradbury JP (1975) Diatom stratigraphy and human settlement in Minnesota. Geol Soc Am Spec Pap 171:1-74

Brodersen KP, Anderson NJ (2002) Distribution of chironomids (Diptera) in low Arctic West Greenland lakes: Trophic conditions, temperature and environmental reconstruction. Freshw Biol 47:1137-1157

Cappelen J, Jørgensen BV, Laursen EV, Stannius LS, Thomsen RS(2001)The observed climate of Greenland, 1958-1999with climatological standard normals 1961-1990. Technical report 00-18 Danish Meteorological Institute

Cremer H, Melles M, Wagner B (2001) Holocene climate changes reflected in a diatom succession from Basaltsø, East Greenland. Can J Bot 79:649-656

D'Andrea W, Huang Y, Fritz SC, Anderson NJ (2011) Abrupt Holocene climate change as an important factor for human migration in West Greenland. Proc Nat Acad Sci USA 108:9765-9769

Dahl-Jensen D,Mosegaard K, Gundestrup N, Clow GD, Johnsen SJ, HansenAW, BallingN(1998) Past temperatures directly from the Greenland Ice Sheet. Science 282:268-271

Deevey ES (1942) Studies on Connecticut lake sediments. III. The biostratonomy of Linsley Pond. Am J Sci 240:233-264

Engstrom DR, Hansen BCS (1985) Postglacial vegetation change and soil development in southeastern Labrador as inferred from pollen and chemical stratigraphy. Can J Bot 63:543-561

Engstrom DR, Fritz SC, Almendinger JW, Juggins S (2000) Chemical and biological trends during lake evolution in recently deglaciated terrain. Nature 408:161-166

Escher A, Sorensen K, Zeck HP (1976) Nagssugtoqidian mobile belt in West Greenland. In: Escher A, WattWS (eds) Geology of Greenland. Grønlands Geologiske Undersøgelse, København, pp 76-95

Foged N (1953) Diatoms from west Greenland. Medd om Groenland 147:1-86

Foged N (1955) Diatoms from Peary Land, North Greenland. Medd om Groenland 128(7):1-90

Foged N (1972) The diatoms in four postglacial deposits in Greenland. Medd om Groenland 194(4):1-66
Foged N (1977) The diatoms in four postglacial deposits at Godthabsfjord, West Greenland. Medd om Groenland 199(4):1-64

Ford MS (1990) A 10 000-yr history of natural ecosystem acidification. Ecol Monogr 60:57-89

Fredskild B (1983) The Holocene development of some low and high arctic Greenland lakes. Hydrobiologia 103:217-224

Fredskild B (1985) Holocene pollen records from West Greenland. In: Andrews JT (ed) Quaternary environments. Eastern Canadian Arctic, Baffin Bay and western Greenland. Allen \& Unwin, Boston, pp 641-681

Fritsch FN, Carlson RE (1980) Monotone piecewise cubic interpolation. SIAM J Numer Anal 17:238-246

Fritz SC, Juggins S, Engstrom DR (2004) Patterns of early lake evolution in boreal landscapes: A comparison of stratigraphic inferences with a modern chronosequence in Glacier Bay, Alaska. Holocene 14:828-840

Funder S, Weidick A (1991) Holocene boreal molluscs in Greenland-palaeoceanographic implications. Palaeogeogr Palaeoclimatol Palaeoecol 85:123-135

Gardner AS, Moholdt G, Wouters B, Wolken G, Burgess DO, Sharp MJ, Cogley G, Braun C, Labine C (2011) Sharply increased mass loss from glaciers and ice caps in the Canadian Arctic Archipelago. Nature 473:357-360

Grimm EC (1987) CONISS: A FORTRAN 77 program for stratigraphically constrained cluster analysis by the method of incremental sum of squares. Comput Geosci 13:13-35

Heggen MP, Birks HH, Anderson NJ (2010) Long-term ecosystem dynamics of a small lake and its catchment in west Greenland. Holocene 20:1207-1222

Heiri O, Lotter AF, Lemcke G (2001) Loss on ignition as a method for estimating organic and carbonate content in sediments: Reproducibility and comparability of results. J Paleolimnol 25:101-110

Holland MM, Bitz CM (2003) Polar amplification of climate change in the Coupled Model Intercomparison Project. Clim Dyn 21:221-232

Kelly M (1985) A review of the Quaternary geology of western Greenland. In: Andrews JT (ed) Quaternary environments. Eastern Canadian Arctic, Baffin Bay and western Greenland, Allen \& Unwin, Boston, pp 461-501

Krammer K, Lange-Bertalot H (1986) Bacillariophyceae 1, teil: Naviculaceae. In: Ettl H, Gerloff J, Heynig H, Mollenhauer D (eds) Süsswasser flora von Mitteleuropa, Band 2/1. Gustav Fischer Verlag, New York

Krammer K, Lange-Bertalot H (1988) Bacillariophyceae. 2, teil: Bacillariaceae, Epithemiaceae, Surirellaceae. In: Ettl H, Gerloff J, Heynig H, Mollenhauer D (eds) Süsswasserflora von Mitteleuropa, Band 2/2. VEB Gustav Fischer Verlag, Jena

Krammer K, Lange-Bertalot H (1991a) Bacillariophyceae. 3, teil: Centrales, Fragilariaceae, Eunotiaceae. In: Ettl H, Gerloff J, Heynig H, Mollenhauer D (eds) Süsswasserflora von Mitteleuropa, Band 2/3. Gustav Fischer Verlag, Stuttgart

Krammer K, Lange-Bertalot H (1991b) Bacillariophyceae. 4, teil: Achnanthaceae, Kritische Ergänzungen zu Navicula (Lineolatae) und Gomphonema,GesamtliteraturverzeichnisTeil 1-4. In: Ettl H, Gärtner G, Gerloff J, Heynig H, Mollenhauer D (eds) Süsswasserflora von Mitteleuropa, Band 2/4. Gustav Fischer Verlag, Jena 
Leng M, Anderson NJ (2003) Isotopic variations in modern lake waters from western Greenland. Holocene 13:605-611

Massa C, Perren B, Gauthier É, Bichet V, Petit C, Richard H (2012) A multiproxy evaluation of Holocene environmental change from Lake Igaliku, South Greenland. J Paleolimnol 48:241-258

Masson-Delmotte V, Jouzel J, Landais A, Stievenard M, Johnsen SJ, White JWC, Werner M, Sveinbjornsdottir A, Fuhrer K (2005) GRIP deuterium excess reveals rapid and orbitalscale changes in Greenland moisture origin. Science 309: 118-121

McGowan S, Ryves DB, Anderson NJ (2003) Holocene records of effective precipitation in West Greenland. Holocene 13: 239-249

McGowan S, Juhler RK, Anderson NJ (2008) Autotrophic response to lake age, conductivity and temperature in two West Greenland lakes. J Paleolimnol 39:301-317

Michelutti N, Wolfe AP, Briner JP, Miller GH (2007) Climatically controlled chemical and biological development in Arctic lakes. J Geophys Res 112:G03002. doi:10.1029/ 2006JG000396

O’Brien SR, Mayewski PA, Meeker LD, Meese DA, Twickler MS, Whitlow SI (1995) Complexity of Holocene climate as reconstructed from a Greenland ice core. Science 270: 1962-1964

Pennington W (1943) Lake sediments: The bottom deposits of the North Basin of Windermere, with special reference to the diatom succession. New Phytol 42:1-27

Pennington W (1978) Responses of some British lakes to past changes in land use on their catchments. Verh Internat Verein Limnol 20:636-641

Perren BB (2007) Holocene lake ontogeny and recent environmental change in West Greenland. Unpublished thesis, University of Toronto

Perren BB, Bradley RS, Francus P (2003) Rapid lacustrine response to recent high arctic warming: A diatom record from Sawtooth Lake, Ellesmere Island, Nunavut. Arct Antarct Alp Res 35(3):271-278

Perren BB, Douglas MSV, Anderson NJ (2009) Diatoms reveal complex spatial and temporal patterns of recent limnological change in West Greenland. J Paleolimnol 42:233-247

Pla S, Anderson NJ (2005) Environmental factors correlated with chrysophyte cyst assemblages in low arctic lakes of southwest Greenland. J Phycol 41:957-974

Renberg I (1990a) A 12,600 year perspective on the acidification of Lilla O" resjo"n, southwest Sweden. Phil Trans R Soc Lond B 327:357-361

Renberg I (1990b) A procedure for preparing large sets of diatom slides from sediment cores. J Paleolimnol 4:87-90

Rignot E, Velicogna I, van den Broeke MR, Monaghan A, Lenaerts J (2011) Acceleration of the contribution of the Greenland and Antarctic ice sheets to sea level rise. Geophys Res Lett 38:L05503. doi:10.1029/2011g1046583

Rühland K, Paterson AM, Smol JP (2008) Hemispheric-scale patterns of climate-related shifts in planktonic diatoms from North American and European lakes. Glob Chang Biol 14:1-15

Ryves DB, McGowan S, Anderson NJ (2002) Development and evaluation of a diatom-conductivity model from lakes in West Greenland. Freshw Biol 47:995-1014
Saros JE, Michel TJ, Interlandi S, Wolfe AP (2005) Resource physiologies of Asterionella formosa and Fragilaria crotonensis in oligotrophic alpine lakes:implications for recent phytoplankton community reorganizations. Can J Fish Aquat Sci 62:1681-1889

Serreze MC, Barrett AP, Stroeve JC, Kindig DN, Holland MM (2009) The emergence of surface-based Arctic amplification. Cryosphere 3:11-19

Smol JP, Wolfe AP, Birks HJB, Douglas MSV, Jones VJ, Korhola A, Pienitz R, Rühland K, Sorvari S, Antoniades D, Brooks SJ, Fallu MA, Hughes M, Keatley BE, Laing TE, Michelutti N, Nazarova L, Nyman M, Paterson AM, Perren B, Quinlan R, Rautio M, Saulnier-Talbot E, Siitonen S, Solovieva N, Weckstrom J (2005) Climate-driven regime shifts in the biological communities of Arctic lakes. Proc Nat Acad Sci USA 102:4397-4402

Stuiver M, Reimer PJ (1993) Extended ${ }^{14} \mathrm{C}$ database and revised CALIB radiocarbon calibration program. Radiocarbon $35: 215-230$

Trenberth KE, Jones PD, Ambenje P, Bojariu P, Easterling D, Klein Tank A, Parker D, Rahimzadeh F, Renwick JA, Rusticucci M, Soden B, Zhai P (2007) Observations: Surface and atmospheric climate change. In: Solomon S, Qin D, Manning M, Chen Z, Marquis M, Averyt KB, Tignor T, Miller HL (eds) Climate change 2007: The physical science basis. Contribution of Working Group I to the 4th Assessment Report of the IPCC Cambridge University Press, Cambridge, UK

van Tatenhove FG, Van der Meer JJM, Koster EA (1996) Implications for deglaciation chronology from new AMSage determinations in central West Greenland. Quat Res 45:245-253

Vinther BM et al (2009) Holocene thinning of the Greenland ice sheet. Nature 461:385-388

Whitehead DR, Charles DF, Jackson ST, Smol JP, Engstrom DR (1989) The developmental history of Adirondack (NY) lakes. J Paleolimnol 2:185-206

Willemse NW, Koster EA, Hoogakker B, van Tatenhove FGM (2003) A continuous record of Holocene eolian activity in West Greenland. Quat Res 59:322-334

Wilson CR, Michelutti N, Cooke CA, Briner JP, Wolfe AP, Smol JP (2012) Arctic lake ontogeny across multiple interglacials. Quat Sci Rev 31:112-126

Winder M, Reuter JE, Schladow SG (2009) Lake warming favours small-sized planktonic diatom species. Proc R Soc Lond B Biol Sci 276:427-435

Wolfe AP (1996) Spatial patterns of modern diatom distribution and multiple paleolimnological records from a small nonglacial Arctic lake, Baffin Island, Northwest Territories. Can J Bot 74:345-359

Wolfe AP, Miller GH, Olsen CA, Forman SL, Doran PT, Holmgren SU (2004) Geochronology of high latitude lake sediments. In: Pienitz R, Douglas MSV, Smol JP (eds) Long-term environmental change in arctic and antarctic lakes. Developments in paleoenvironmental research, vol 8. Springer, Dordrecht, pp 19-52

Wolfe AP, Vinebrooke RD, Michelutti N, Rivard B, Das B (2006) Experimental calibration of lake-sediment spectral reflectance to chlorophyll $a$ concentrations: Methodology and paleolimnological validation. J Paleolimnol 36:91-100 